\title{
Malignant infantile osteopetrosis presenting with neonatal hypocalcaemia
}

\author{
Madhusudan Srinivasan, Mario Abinun, Andrew J Cant, Kelvin Tan, Anthony Oakhill, \\ Colin G Steward
}

\begin{abstract}
Presentation characteristics were reviewed in 14 children from 12 families with malignant infantile osteopetrosis seen at two large referral centres for bone marrow transplantation. Children from six of these families presented initially with symptoms of hypocalcaemia. These comprised early or late neonatal convulsions in six cases (corrected serum calcium $<1.5 \mathrm{mmol} / \mathrm{l}$ ), and vomiting and irritability (serum calcium $1.68 \mathrm{mmol} / \mathrm{l}$ ) in another. One other related child had severe and persistent jittering episodes almost certainly attributable to hypocalcaemia. In seven of eight cases, these symptoms developed during the first 14 days of life. Although occasionally reported previously, malignant infantile osteopetrosis remains essentially unrecognised as a cause of neonatal hypocalcaemia, often resulting in diagnostic confusion and delay. This is important in the context of curative haemopoietic stem cell transplantation where preservation of sight may depend on early intervention.
\end{abstract} (Arch Dis Child Fetal Neonatal Ed 2000;83:F21-F23)

Keywords: neonatal; hypocalcaemia; malignant infantile osteopetrosis; bone; osteosclerosis; visual impairment

Malignant infantile osteopetrosis (MIOP) is a rare inherited bone disease characterised by reduced or dysregulated activity of osteoclasts, resulting in generalised osteosclerosis (fig 1A). ${ }^{1}$ Overgrowth of cranial nerve foramina and the foramen magnum results in nerve compression-progressively affecting the optic, facial, oculomotor, and auditory nerves - and hydrocephalus. ${ }^{2}$ Other problems include irritability, snuffling because of disruption of nasal architecture, ${ }^{3-4}$ hepatosplenomegaly (the result of extramedullary haemopoiesis), and eventually hypersplenism. Failure to thrive and increased infections because of an unexplained defect in neutrophil superoxide function are also characteristic. ${ }^{5}$

In the natural course of the disease, $70 \%$ of children die within the first six years. ${ }^{6}$ Most of the remainder have a very poor quality of life and die by the age of 10 . With the exception of a very small proportion of cases characterised by primary neurodegenerative disease ${ }^{7-11}$ bone marrow transplantation (BMT) is curative, as osteoclasts are derived from bone marrow precursors. About two thirds of children are cured by BMT from matched sibling donors. ${ }^{12}$ Historically, the use of alternative (non-sibling) donors has yielded very poor results because of a combination of high rejection rates and other transplant complications. However, there are now encouraging signs that the use of high dose, highly $\mathrm{T}$ lymphocyte depleted, parental marrow or peripheral blood stem cell transplants can improve outcome for those lacking a family donor (W Friedrich and T Klingebiel, personal communication).

The commonest presentations result from optic nerve compression in the first year of life. ${ }^{6}$ This may result in failure to establish fixation and nystagmus, or slightly later development of strabismus. ${ }^{13}$ Unfortunately, one of the most disappointing aspects of transplantation is the rarity of reversal of these symptoms. ${ }^{12}$ Therefore it is crucial to identify affected children at the earliest possible stage and to perform BMT with relative urgency. This is particularly true now that suitable donors (either sibling or haploidentical) can be found for all patients with only minimal delay.
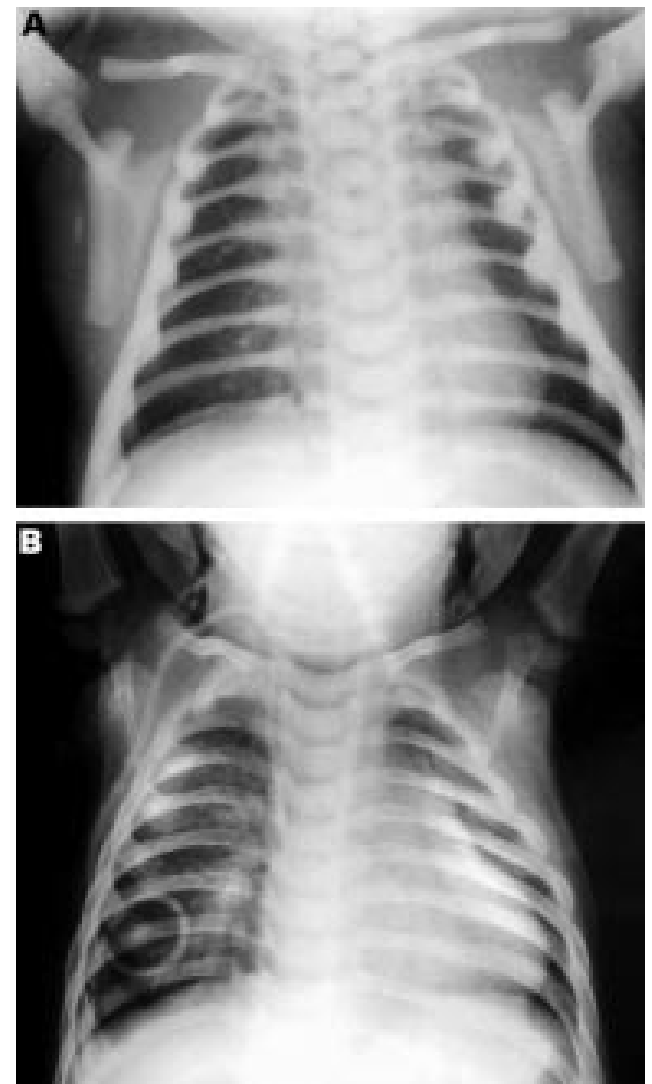

Figure 1 Representative chest radiographs before and after successful unrelated donor bone marrow transplantation. At diagnosis $(A)$ there is generalised osteosclerosis. There is appreciable improvement in both bone density and modelling by nine months after the transplant $(B)$. 
Table 1 Characteristics of presentation in children with hypocalcaemia secondary to malignant infantile osteopetrosis

\begin{tabular}{|c|c|c|c|c|}
\hline$U P N$ & $\begin{array}{l}\text { Age when } \\
\text { hypocalcaemic } \\
\text { (days) }\end{array}$ & Initial symptoms & $\begin{array}{l}\text { Age at } \\
\text { diagnosis } \\
\text { (days) }\end{array}$ & $\begin{array}{l}\text { Additional features at } \\
\text { diagnosis }\end{array}$ \\
\hline 1 & 1 & Focal convulsion & 1 & \\
\hline 2 & 4 & $\begin{array}{l}\text { Focal fitting } \\
\text { Snuffling }\end{array}$ & 10 & \\
\hline $3 \mathrm{~B}$ & 5 & Generalised convulsion & 2 & \\
\hline $3 \mathrm{~A}$ & $<14$ & $\begin{array}{l}\text { Severe jittering during first } \\
2 \text { weeks }\end{array}$ & 60 & $\begin{array}{l}\text { Macrocephaly } \\
\text { Visual failure } \\
\text { Hepatosplenomegaly }\end{array}$ \\
\hline 4 & 8 & $\begin{array}{l}\text { Poor feeding } \\
\text { Twitching } \\
\text { Brief "spasms" }\end{array}$ & 76 & $\begin{array}{l}\text { Visual failure } \\
\text { Anaemia } \\
\text { Macrocephaly } \\
\text { Snuffling }\end{array}$ \\
\hline $5 \mathrm{~B}$ & 10 & $\begin{array}{l}\text { Jaundice } \\
\text { Vomiting } \\
\text { Snuffling }\end{array}$ & 30 & \\
\hline 6 & 14 & Generalised convulsions & 210 & $\begin{array}{l}\text { Visual failure } \\
\text { Anaemia } \\
\text { Hepatosplenomegaly } \\
\text { Macrocephaly } \\
\text { Snuffling }\end{array}$ \\
\hline $5 \mathrm{~A}$ & 43 & $\begin{array}{l}\text { Snuffling } \\
\text { Generalised convulsions }\end{array}$ & 43 & \\
\hline
\end{tabular}

When there were two affected children within a family, these are denoted A or B according to their order of birth. Child $3 \mathrm{~B}$ was diagnosed by routine $\mathrm{x}$ ray examination on day 2 because of the previous family history.

UPN, unique patient number. caemia, ranked according to age at first symptomatic presentation. Table 2 gives details, where available, of plasma corrected calcium, together with plasma phosphate, alkaline phosphatase, parathormone, and 25hydroxyvitamin $\mathrm{D}$ assays.

Although recorded in the medical notes as being hypocalcaemic when presenting with convulsions, laboratory results are no longer available in UPN 2. Patient UPN 3A (the sibling of UPN 3B who had late neonatal convulsions) had severe and persistent jittering episodes during the first two weeks of life. These were a common cause of complaint to the family's health visitor and are presumed to have been secondary to hypocalcaemia, although blood tests were never performed.

\section{HYPOCALCAEMIC FEATURES}

Six children presented with hypocalcaemic convulsions (corrected plasma calcium $<1.7$ $\mathrm{mmol} / \mathrm{l}$ ) between day 1 and 43 of life. In only one of these (UPN 6) was a cause suggested (maternal hypovitaminosis D). A further child presented with physiological jaundice, vomiting, and snuffling at 10 days of age but was found to have a serum calcium of $1.68 \mathrm{mmol} / 1$. The presence of a previous child with MIOP in this family had led to attempted antenatal diagnosis by third trimester radiography, ${ }^{14}$ but this was unremarkable. Hypocalcaemia prompted further radiography and hence diagnosis.

Including the child with jittering episodes, eight of 14 children therefore had definite or presumed symptomatic hypocalcaemia during the first month of life. The diagnosis of MIOP was quickly established or already known in five of these eight cases. However, in the remaining children, diagnosis was delayed by 50,68 , and 200 days, by which time all three had developed visual failure.

Mean age at presentation for children with proven hypocalcaemia was 12.4 days. This contrasted with an average of 6.6 months for children presenting with more widely recognised symptoms - for example, nystagmus, hepatosplenomegaly, macrocephaly, and cytopenias.

\section{BONE MARROW TRANSPLANTATION}

Ten children underwent BMT at the Bristol Royal Hospital for Sick Children, Newcastle General Hospital, or Hospital for Sick Children, Great Ormond Street; in seven the bone marrow was from unrelated donors, in one it was from a haploidentical donor, in one from a matched sibling, and another from a one anti-

Table 1 gives age at presentation and clinical features of children presenting with hypocal-

Table 2 Biochemical parameters at presentation

\begin{tabular}{lllllll}
\hline UPN & Gestation & $\begin{array}{l}\text { Corrected serum } \\
\text { calcium }(\text { mmol/l) }\end{array}$ & $\begin{array}{l}\text { Serum } \\
\text { phosphate } \\
(\text { mmolll) }\end{array}$ & $\begin{array}{l}\text { Alkaline } \\
\text { phosphatase } \\
\text { (units/l) }\end{array}$ & $\begin{array}{l}\text { Serum parathormone } \\
(\text { pg/ml) }\end{array}$ & $\begin{array}{l}\text { Serum 25OH } \\
\text { vitamin D (mmol/l) }\end{array}$ \\
\hline 1 & $38 / 40$ & 1.3 & 1.79 & 345 & 28.7 & 39 \\
3B & Full term & 1.43 & 1.56 & 206 & 3.2 & 36.3 \\
4 & $38 / 40$ & 1.0 & NA & NA & 210 & NT \\
5A & $38 / 40$ & 1.41 & 1.3 & 101 & NT & 20 \\
5B & $38 / 40$ & 1.68 & 0.96 & 672 & 105 & 13.9 \\
6 & Full term & 1.40 & 1.52 & 216 & 105 & \\
\hline
\end{tabular}

Results are no longer available in patient UPN 2, although hypocalcaemic convulsions were well documented. Blood tests were not performed in patient $3 \mathrm{~A}$.

UPN, unique patient number; NT, not tested; NA, not available. 


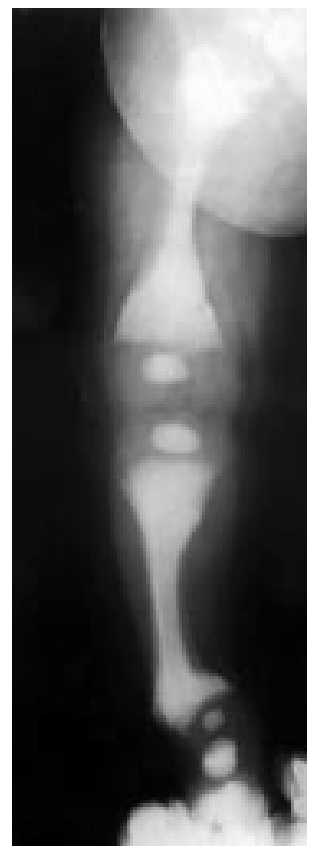

Figure 2 Plain radiograph of right lower limb showing generalised osteosclerosis and a "bone within a bone" appearance. The metaphyses are irregular and there is varus deformity of the distal tibia and proximal femur. These are characteristic appearances of osteopetrosis and secondary rickets. gen mismatched sibling. Only two survive: one who received a matched sibling transplant at 6 months of age and the other a $\mathrm{T}$ cell depleted matched unrelated donor transplant at 6 weeks. Both patients have normal bone density, visual acuity and fields, and are free of all symptoms of disease three and five years after the transplantation. The second of these patients has a strabismus, thought to be familial in origin and improving with age.

\section{Discussion}

Disturbance of calcium homoeostasis has been well described in MIOP. The first description may have been that by Avery et al, ${ }^{15}$ who described a baby born with osteopetrosis in 1956 who was a "bit twitchy" at 6 days of age. Subsequently, in a large survey of European patients, Gerritsen et $a l^{6}$ reported 23 children who had serum calcium measured at presentation. Three children (from separate families) presented with convulsions at less than 1 month of age and had serum calcium levels of $<1.5 \mathrm{mmol} / 1$. Seven others had levels of $1.5-2.0 \mathrm{mmol} / 1$.

In the neonatal period, children are functionally relatively hypoparathyroid. In this setting, normal osteoblast function, unbalanced by compensatory osteoclast function, pushes some osteopetrotic children into hypocalcaemia. The impact of this relative imprisonment of calcium stores is shown most neatly by the development of early rickets in some children (fig 2). ${ }^{16}{ }^{17}$ This has been elegantly termed a "paradox of plenty". ${ }^{17}$ Our series, in conjunction with the observations of Avery et al and Gerritsen et al, show that this window during which MIOP presents with hypocalcaemia is very narrow-all cases have occurred within the first 43 days, most within the first two weeks.

It could be argued that the high incidence of hypocalcaemic presentation seen in this series reflects a common ancestry. However, the geographical distribution and family histories lend no support to this hypothesis. Clearly, genetic analysis would help to exclude such a founder defect. However, the quest for gene defects responsible for human osteopetrosis is currently proving elusive (in contrast with animal models in which a variety of gene defects-for example, CSF-1, c-src-have been established). ${ }^{18}$ This may reflect the presence of a number of separate defects all resulting in osteoclast dysfunction.

The importance of early diagnosis and treatment cannot be stressed too highly. Both of the patients who are alive in this series were transplanted by 6 months of age and retain perfect vision. Furthermore, although established optic atrophy is irreversible, there are well documented cases of visual improvement after transplant. ${ }^{12}{ }^{19}$ These are presumably children in whom occlusion of the vascular supply to the optic nerve is compromised by bony overgrowth but not yet critically occluded.
With the advent of increasingly safe and refined techniques of haploidentical stem cell transplantation, which for the first time brings the possibility of rapid treatment for most children, early diagnosis is paramount. The absence of MIOP from the differential diagnosis of neonatal hypocalcaemia contributed in this series to a diagnostic delay of up to six months. This oversight must be corrected if this is to be avoided and the chances of transplantation to preserve visual and other cranial nerve function maximised. We therefore recommend that a plain radiograph of the knee or wrist be included in the routine investigation of children with "idiopathic" neonatal hypocalcaemia.

We thank Dr Janet Stone and Mrs Angela Brimble for help with specimens, Professor David Davies and Drs Mike Williams, Thomas Turner, and Tim French for patient referrals and clinical details, and Dr David Grier for sample radiographs. We particularly wish to record the important contribution of Dr Marius Lemon who died before he could see this project completed and is missed greatly by many colleagues in Bristol.

1 Singer FR, Chang SS. Osteopetrosis. Semin Nephrol 1992;12:191-9.

2 Shapiro F. Osteopetrosis. Current clinical considerations. Clin Orthop 1993;294:34-44.

3 Elster AD, Theros EG, Key LL, Chen MY. Cranial imaging in autosomal recessive osteopetrosis. Part I. Facial bones and calvarium. Radiology 1992;183:129-35.

4 Bartynski WS, Barnes PD, Wallman JK. Cranial CT of autosomal recessive osteopetrosis. American fournal of Neuroradiology 1989;10:543-50.

5 Key LLJ, Ries WL, Rodriguiz RM, Hatcher HC. Recombinant human interferon gamma therapy for osteopetrosis. 7 Pediatr 1992;121:119-24.

6 Gerritsen EJ, Vossen JM, van Loo IH, et al. Autosomal recessive osteopetrosis: variability of findings at diagnosis and during the natural course. Pediatrics 1994;93:247-53.

7 Fitch N, Carpenter S, Lachance RC, et al. Prenatal axonal dystrophy and osteopetrosis. Arch Pathol 1973;95:298301

8 Ambler MW, Trice J, Grauerholz J, O'Shea PA. Infantile osteopetrosis and neuronal storage disease. Neurology 1983;33:437-41.

9 Jagadha V, Halliday WC, Becker LE, Hinton D. The association of infantile osteopetrosis and neuronal storage disease in two brothers. Acta Neuropathologica 1988;75:233-40.

10 Takahashi K, Naito M, Yamamura F, et al. Infantile osteopetrosis complicating neuronal ceroid lipofuscinosis. Pathology, Research and Practice 1990;186:697-706.

11 Abinun M, Newson T, Rowe PW, Flood TJ, Cant AJ. Importance of neurological assessment before bone marrow transplantation for osteopetrosis. Arch Dis Child marrow transplant $1999 ; 80: 273-4$.

12 Gerritsen EJ, Vossen JM, Fasth A, et al. Bone marrow transplantation for autosomal recessive osteopetrosis. A report from the working party on inborn errors of the European Bone Marrow Transplantation Group. $\mathcal{f}$ Pediatr 1994;125:896-902.

13 Ainsworth JR, Bryce IG, Dudgeon J. Visual loss in infantile osteopetrosis. $\mathcal{F}$ Pediatr Ophthalmol Strabismus 1993;30:201-3.

14 Ogur G, Ogur E, Celasun B, et al. Prenatal diagnosis of autosomal recessive osteopetrosis, infantile type, by X-ray evaluation. Prenat Diagn 1995;15:477-81

15 Avery ME, Dorst JP, Walker DG. Osteopetrosis. In: Bergsma D, ed. Clinical Delineation of Birth Defects. IV. Skeletal Dysplasia. New York: Mosby, 1969:305-11.

16 Oliveira G, Boechat MI, Amaral SM, Young LW. Osteopetrosis and rickets: an intriguing association. American fournal of Diseases of Children 1986;140:377-8.

17 Kaplan FS, August CS, Fallon MD, Gannon F, Haddad JG. Osteopetrorickets. The paradox of plenty. Pathophysiology and treatment. Clin Orthop 1993;294:64-78

18 Felix R, Hofstetter W, Cecchini MG. Recent developments in the understanding of the pathophysiology of osteopetrosis. Eur F Endocrinol 1996;134:143-56.

19 Solh H, Da CA, Giri N, et al. Bone marrow transplantation for infantile malignant osteopetrosis. $f$ Pediatr Hematol Oncol 1995;17:350-5. 